\title{
Four poems
}

Edward R. Wolpow, MD

Neurology ${ }^{\circledR}$ 2018;91:887-888. doi:10.1212/WNL.0000000000006475

\section{Synesthesia}

Mozart's parakeet

Of which so little is known.

Are those blue feathers

To start the string quartet No. 21

In $\mathrm{D}$ major, K. 575

Or green?

\section{Epic}

Odysseus, long-disguised

Took his place in Ortho Clinic

About a particularly sore lumbar stitch

Ever since his suspension

Supine beneath a greasy sheep

At Polyphemus' doorstep.

Indifferent providers

Ill-befitting royalty.

Routine scans scrawled prescription new appointment

But the jig was up when

They solicited a copay and he trashed the place

Which is the real reason

Penelope's suitors got theirs

And the constellations

Changed.

\section{Double vision}

Show the radiologist the MR.

There are 2 choices:

Nothing but the age

No dialog

No hints where to look especially hard

A blind sanitary interpretation

Dripping fairness and great distances.

Blind justice could be holding a frying pan

She would never know.

Lots of fluff, the whole sad story.

Headaches enough for a family reunion.

Lab numbers. Vital sighs. Unscripted by

Conan Doyle-lots of extranea.

Look really hard at the right thalamus.

\section{Correspondence}

Dr. Wolpow

wolpoweg@comcast.net

\section{ค Audio}

Listen to Dr. Wolpow read these poems.

NPub.org/vofllp 
Go on-call it-we know it's there.

Overturn the resident's normal report.

The lady with the blindfold

Would never know.

Does Van Gogh's mania matter?

What of Paul Klee's scleroderma?

Kandinsky was a refugee.

Doc, are you a census-taker?

Doc, are you a story-teller?

\section{Gifting}

She gave her son a train set

So soon the cars did run.

She gave her son a sunset

So soon he built a sun. 


\title{
Neurology
}

\author{
Four poems \\ Edward R. Wolpow \\ Neurology 2018;91;887-888 \\ DOI 10.1212/WNL.0000000000006475
}

This information is current as of November 5, 2018

\section{Updated Information \& Services}

\section{Subspecialty Collections}

\section{Permissions \& Licensing}

Reprints including high resolution figures, can be found at: http://n.neurology.org/content/91/19/887.full

This article, along with others on similar topics, appears in the following collection(s):

\section{All Clinical Neurology}

http://n.neurology.org/cgi/collection/all_clinical_neurology

\section{All Education}

http://n.neurology.org/cgi/collection/all_education

Clinical neurology history

http://n.neurology.org/cgi/collection/clinical_neurology_history

Information about reproducing this article in parts (figures,tables) or in its entirety can be found online at:

http://www.neurology.org/about/about_the_journal\#permissions

Information about ordering reprints can be found online:

http://n.neurology.org/subscribers/advertise

Neurology ${ }^{\circledR}$ is the official journal of the American Academy of Neurology. Published continuously since 1951, it is now a weekly with 48 issues per year. Copyright (O) 2018 American Academy of Neurology. All rights reserved. Print ISSN: 0028-3878. Online ISSN: 1526-632X.

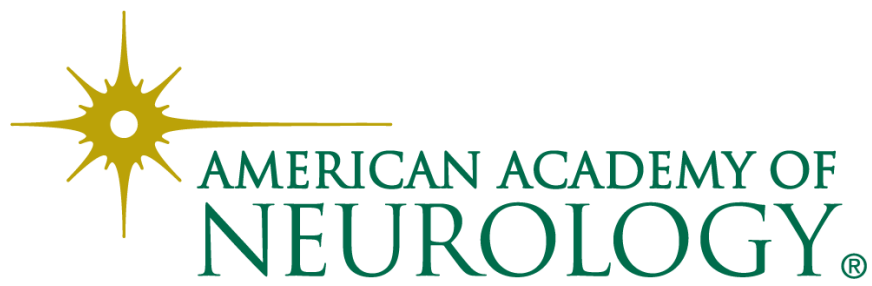

